\title{
The Bioelectricity of Tofu Wastewater in Microalgae-Microbial Fuel Cell (MMFC) System
}

\author{
Anang Baharuddin Sahaq ${ }^{1}$, Hadiyanto ${ }^{2}$ \\ Student, Department of Chemical Engineering, Diponegoro University, Semarang, Indonesia ${ }^{1}$ \\ Lecturer, Department of Chemical Engineering, Diponegoro University, Semarang, Indonesia ${ }^{2}$
}

\begin{abstract}
The large number of tofu industries spread in many cities in Indonesia produces a lot of liquid and solid waste. Tofu industrial wastewater is known to contain high COD so it must be processed before being disposed of into the environment. This research studies the reduction of tofu liquid waste COD and uses it as a power plant using the Microbial Fuel Cell (MFC) system. In addition, MFC technology is combined with developing spirulina at the cathode. The results showed that electricity amounted to $171.44 \mathrm{~mW} . \mathrm{m}-2$ for 1 electrode and $171.44 \mathrm{~mW} . \mathrm{m}-2$ for 2 electrodes. The percentage of reduction in COD of tofu liquid waste reached 40\% and OD of spirulina biomass reached 0.5.
\end{abstract}

Keywords: Tofu Wastewater; Spirulina; Electricity generation; COD removal

\section{INTRODUCTION}

The tofu industry is one of the fastest growing industries in Indonesia, data from the Ministry of Industry (2015) noted that there are 115,000 tofu industries in Indonesia, the tofu industry produces waste, in the form of solid and liquid waste.

The characteristics of tofu liquid waste contain high organic matter, with this condition the tofu industry wastewater is a potential source of pollution if the waste water produced is immediately disposed of [1].

Processing is needed to reduce pollutant parameters in wastewater so that it does not pollute the environment. One of the processing that can be done to treat wastewater is aerobic processing. Aerobic treatment utilizes microorganisms to decompose organic substances in wastewater where they also produce energy.

The use of microbial fuel cells has been developed for various purposes of energy generation. One of them is used to generate electricity through the fuel cell. Fuel cell is environmentally friendly because it does not produce pollution, it can even be used to overcome environmental problems by recycling waste into an energy source.

Microbial fuel cell (MFC) is one type of biofuel cells [2]. MFC is a system or device that uses bacteria as a catalyst to oxidize organic and inorganic materials. Electrons are produced by bacteria from the substrate which are then transferred to the anode and flowed to the cathode which is connected by a conductivity device including a resistor to produce electricity [3].

The reactions that occur in MFC are shown in equations (1) and (2), namely:

Reaction at the anode:

$\mathrm{C}_{6} \mathrm{H}_{12} \mathrm{O}_{6}+\mathrm{H}_{2} \mathrm{O} 6 \mathrm{CO}_{2}+24 \mathrm{e}^{-}+24 \mathrm{H}^{+}(1)$

Reaction at the cathode:

$\mathrm{O}_{2}+4 \mathrm{e}^{-}+4 \mathrm{H}^{+} 2 \mathrm{H}_{2} \mathrm{O}(2)$

Spirulina sp. is a multicellular microalgae belonging to the group filamentous microscopic cyanobacterium, has a spiral width between 26-36 $\mu \mathrm{m}$ and its spiral length between 43-57 $\mu \mathrm{m}$ [4]. Spirulina sp. Is autotrophic creatures that have a greenish, bluish color, with columned cells forming a twisted filament resembling a spiral (helix) so that it is also called with filamentous green blue algae (cyanobacteria) [5]. 


\section{International Advanced Research Journal in Science, Engineering and Technology}

Vol. 6, Issue 7, July 2019

\section{EXPERIMENTAL METHOD}

The MMFC system in this study uses media consisting of chamber cathodes and chamber anodes. The anode and cathode are connected to a Nafion 117 Proton Exchange Membrane (PEM) Membrane. This study varied the number of electrodes on the cathode and chamber anode. The cathode used is graphite with a length of $10 \mathrm{~cm}$ and a diameter of 8 $\mathrm{mm}$ which is connected with a copper cable connected to the circuit.

In the cathode chamber, Spirulina Platensis microalgae were cultivated. To supply the light energy needed by spirulina, lamp $11 \mathrm{~W}$. is used Digital Multimeters are used to monitor the electricity produced by MMFC. This MMFC study was conducted in the laboratory of Diponegoro University, Semarang. Measurement of reduction in COD of tofu liquid waste is carried out every day according to the standard method. The resulting electricity measurements are carried out every day with a Digital Multimeter.

\section{RESULT AND DISCUSSION}

The results of the observation of the Fuel Cell operation:

A. Biomass Production of MMFC in Time

The graph of Spirulina Platensis growth during the operation is presented in Figure 1.

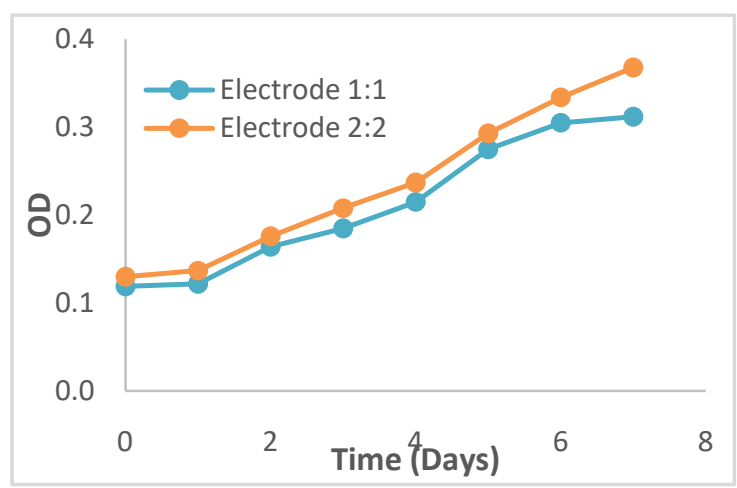

Fig 1. Biomass Production of MMFC in Time

Fig. 1 shows the growth of spirulina during MMFC operation. From the table above it can be seen that the density of spirulina cultivation reached the highest value on day 7 with Optical Density (OD) of 0.368 . From the graph above it can be seen that the growth of microalgae every day tends to increase. The density of microalgae has increased until it reaches its peak on the day 7 .

B. Bioelectricity Production in MMFC System

The graph of Bioelectricity Production during the operation is presented in Figure 2.

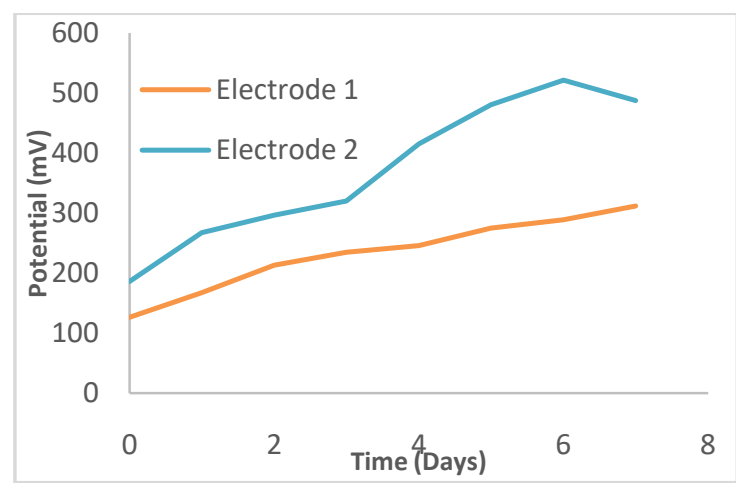

Fig. 2. Bioelectricity Production in MMFC System 


\section{International Advanced Research Journal in Science, Engineering and Technology}

Vol. 6, Issue 7, July 2019

Fig. 2 shows the voltage comparison of 1:1 and 2:2 electrode ratio. From the results obtained, it shows the highest voltage generated from tofu liquid waste which is $521 \mathrm{mV}$ at 2: 2 electrodes This shows, microbes have adapted to the MFC system so that microbial growth tends to rise along with the electricity produced. However, in the next hour the value of electricity produced decreased. This is due to the absence of additional nutrients which causes microbial growth to enter the death phase.

C. $\quad$ COD Profile of Tofu Wastewater During System

The graph of COD profiile during the operation is presented in Figure 2.

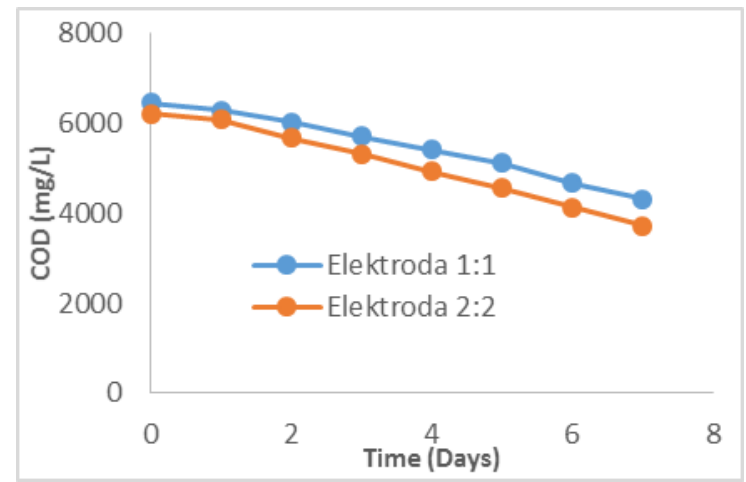

Fig. 3. COD Profile Tofu Wastewater During System

The COD removal performances of the 2 systems with different concentrations show in Fig. 3. Variations in the number of cathodes 1 and 2 give a percentage the decrease in COD was 33.12\%, 40.06\%. This is in accordance with the research Cheng [6] If the surface area gets bigger, the electricity produced will be even greater. Meanwhile, the electricity generated is an indication of the reduction in COD because it has degraded by microbes. In this experiment, the decrease in COD increased when using 2 cathodes. Factors that influence the decrease in COD levels in waste with the MFC system are retention time.

Based on the research conducted, the highest COD reduction efficiency occurred after the MFC process was carried out for 168 hours. In tofu waste media with 1: 1 electrode, COD levels decreased from $6459 \mathrm{mg} / \mathrm{L}$ to $4320 \mathrm{mg} / \mathrm{L}$, while in tofu wastewater with 2: 2 electrode COD levels dropped from $6211 \mathrm{mg} / \mathrm{L}$ to $3723 \mathrm{mg} / \mathrm{L}$.

\section{CONCLUSION}

In this research, MMFC can run well and proven to reduce the COD value of tofu liquid waste up to $40.06 \%$. The bioelectricity produced can reach $521 \mathrm{mV}$ at 2: 2 electrode. This is because microbial activity in tofu wastewater. Spirulina Platensis biomass can grow well in the chamber cathode. This can be seen from a medium that is increasingly concentrated in greenness and OD which is increasing every day.

\section{REFERENCES}

[1]. Herlambang, A. Teknologi Pengolahan Limbah Cair Tahu. Pusat Pengkajian dan Penerapan 79 Teknologi Lingkungan (BPPT) dan Badan Pengendalian Dampak Lingkungan Samarinda. 2002

[2]. H. J. Kim, M.-S. Hyun, I. S. Chang, B. -H. Kim, J. Microbiol. Biotechnol, pp. 365-367. 1999

[3]. B. E. Logan, C. Murano, K. Scott, N. D. Gray, dan I. M. Head, Wat. Res., 39 pp. 942-952.2006

[4]. Yudiati, E., S. Sedjati, dan R. Agustian. 2011. Aktivitas Antioksidan Dan Toksisitas Ekstrak Methanol dan Pigmen Kasar Spirulina sp. J. Ilmu Kelautan. 16(4):187-192.

[5]. Hariyati, R. 2008. Pertumbuhan dan Biomassa Spirulina sp. dalam Skala Laboratorium. J. Biologi. 10(1):19-22.

[6]. S.A. Cheng, H. Liu, B.E. Logan, Environ. Sci. Technol. 40 (2006) 364 